\title{
Effects of Physical Activity on Brain Energy Biomarkers in Alzheimer's Diseases
}

\author{
Khadijeh Ebrahimi ${ }^{1}$, Morteza Jourkesh ${ }^{2, *}$, Saeed Sadigh-Eteghad ${ }^{3}$, Stephen R Stannard ${ }^{4}$, \\ Conrad P. Earnest ${ }^{5}$ (D), Roger Ramsbottom ${ }^{6}$, Jose Antonio ${ }^{7}$ (D) and Khan H. Navin ${ }^{8}$ \\ 1 Department of Sports Science and Physical Education, Marand Branch, Islamic Azad University, \\ Marand 5418916571, Iran; kh.ebrahimi90@gmail.com \\ 2 Department of Physical Education \& Sports Science, Islamic Azad University, \\ Shabestar Branch 5381637181, Iran \\ 3 Neurosciences Research Center, Tabriz University of Medical Sciences, Tabriz 5166614766, Iran; \\ s.sadigh@tbzm.ac.ir \\ 4 School of Sport, Exercise, and Nutrition, Massey University, Palmerston North 4442, New Zealand; \\ srstannard@gmail.com \\ 5 Department of Health and Kinesiology, Texas A\&M University, College Station, TX 77843, USA; \\ cpe.sci@icloud.com \\ 6 Department of Sport, Health Sciences and Social Work, Oxford Brookes University, Oxford OX3 0BP, UK; \\ rramsbottom@brookes.ac.uk \\ 7 Department of Health and Human Performance, Nova Southeastern University, Davie, FL 32004, USA; \\ ja839@nova.edu \\ 8 Immune Whey, Sugar Hill, GA 30518, USA; nkhan30518@gmial.com \\ * Correspondence: mjourkesh@ut.ac.ir
}

Received: 1 April 2020; Accepted: 29 May 2020; Published: 8 June 2020

\begin{abstract}
The prevalence of dementia has substantially increased worldwide. Currently, there is no cure for dementia or Alzheimer's disease (AD), and care for affected patients is financially and psychologically costly. Of late, more attention has been given to preventive interventions-in particular, physical activity/exercise. In this review, examine the risk factors associated with AD and the effects physical activity may play in the prevention of the degenerative process of this disease, loss of memory and cognitive performance in the elderly. To date, research has shown that physical activity, especially aerobic exercise, has a protective effect on cognitive function and memory in the elderly and Alzheimer's patients. In comparison with aerobic exercise, several strength training studies have also shown positive effects, and the rare studies that compare the two different modalities show no difference.
\end{abstract}

Keywords: Alzheimer's; physical activity; prevention and memory

\section{Introduction}

Alzheimer's disease (AD) is the most common cause of dementia and is an age-related neurodegenerative disease which leads to the loss of memory and learning in mid-to-late life [1].Globally, over 50 million people have dementia, Alzheimer's disease being the most common form and responsible for $60-70 \%$ of cases (WHO) [2]. Currently, about ten percent of the population over 65 years, more than 25 million people worldwide, are affected by this disease. More than a century has passed since specialist neurologist Alois Alzheimer described, for the first time, a 51-year-old female patient with a progressively sharp memory decline, brain atrophy, senile plaques (SPs, or neuritic plaque), and neurofibrillary tangles (NFTs) [3]. Senile plaques and NTFs consist of aberrant cumulative extracellular amyloid $\beta$-protein $(A \beta)$ and the hyper-phosphorylation of intracellular 
microtubule-associated protein tau [4]. The most affected areas in the brains of AD patients include the olfactory bulb, neocortex, and hippocampus, [3] which plays a leading role in spatial memory and learning [5]. Despite intensive research into AD and other neurological diseases, no drug has yet been developed to effectively treat all the pathological aspects of the disease or reduce the risk of age-related cognitive disorders and dementia [6]. According to the literature, factors that protect the heart also protect the brain and this may reduce the risk of $\mathrm{AD}$ and other dementia-related diseases [7]. Physical activity, especially aerobic exercise, is one such factor [7] High- and moderate-intensity exercise training also improves cerebrovascular reactivity and this is important for memory, executive function, and mental health [8]. Therefore, the purpose of this article is to review AD risk factors and detail the effect of physical activity on learning, cognitive function and molecular factors affecting Alzheimer's disease.

\section{Risk Factors for Alzheimer's Disease}

Alzheimer's disease is a complex disorder, which may be due to a combination of genetic, biochemical and environmental factors. The biggest risk factor for $\mathrm{AD}$, age, is unmodifiable but the disease is not a normal part of the aging process. Many Alzheimer's patients have no family history of the disease, yet are diagnosed with AD at approximately the age of 65 years and classified as having sporadic Alzheimer's disease (SAD) [7,9].

Without the benefit of experimental data, useful observational studies rely on large numbers of study participants, and meta-analyses to give weight to the evidence. In this regard, the publication of $\mathrm{Xu}$ et al. (2015) provides some clues as to modifiable risk factors in the development of AD. The inclusion of 232 separate studies provide good statistical power, though the results appear inconsistent. For example, whilst physical activity was seen to be protective, low body mass index (BMI) was a risk factor, yet physical activity and BMI levels have been shown to be inversely related to the development of AD [10] Surprisingly, the Xu et al. (2015) meta-analysis showed heart disease and cancer to be be 'protective', but possibly because mortality associated with these reduce the age-related development of $\mathrm{AD}$, or because identification and treatment of these diseases was somehow protective against AD. Nevertheless, and in accord with previous evidence [11], cognitive activity, intake of some specific nutrients (e.g., folate, fish), and physical activity were considered protective. Meanwhile, the impact of light smoking in the development of $\mathrm{AD}$ is less clear, although heavy smoking is a common and major overall risk factor [12].

Some specific genetic factors appear to be involved in the occurrence of $A D$, including the gene apolipoprotein E (APOE) [13,14]. APOE has three major alleles: $\varepsilon 2, \varepsilon 3$ and $\varepsilon 4$ and it has been reported that expression of the $\varepsilon 4$ allele leads to an accelerated loss of nerve function and decreases the onset age of $\mathrm{AD}[15,16]$. About one percent of $\mathrm{AD}$ cases are inherent and thus classified as familial AD (FAD). FAD is associated with mutations of the genes encoding amyloid- $\beta$ precursor protein (APP), presenilin 1 (PS1) or presenilin 2 [9].

\section{Aetology of Alzheimer's Disease}

The most important theory proposed to explain the development of AD is the "amyloid cascade hypothesis" (ACH), which was suggested for the first time in 1992 [17]. According to the ACH theory, the primary pathological event in AD includes $\mathrm{A} \beta$ peptide production and deposition by APP in the brain parenchyma and cerebrospinal fluid, which leads to the formation of SPs, then NFTs, the death of neurons and, eventually, dementia $[18,19]$. There are a wide variety of $A \beta$ forms, including $A \beta 40$ with 40 amino acids and the peptide $\mathrm{A} \beta 42$, the most common type, which is significantly more toxic than $\mathrm{A} \beta 40$ [20]. On the other hand, $A \beta 42$ is the major variant of $A \beta$ in the core of senile plaques, whereas $\mathrm{A} \beta 40$ constitutes $\sim 90 \%$ of total $\mathrm{A} \beta$ in plasma in which, in most FAD cases, the ratio of $\mathrm{A} \beta 42 / \mathrm{A} \beta 40$ is shown to be elevated [21].

APP is cleaved by two alternative pathways: an amyloidogenic and a non-amyloidogenic pathway. In the amyloidogenic pathway, APP is sequentially cleaved by a $\beta$-secretase (BACE1) to generate two 
cleavage fragments, APPs $\beta$ and C99 [22,23]. Successive cleavage of C99 is undertaken by $\gamma$-secretase, generating neurotoxic $\mathrm{A} \beta$ peptides [3,22]. Increased $\mathrm{A} \beta$ production contributes to the etiological basis of Alzheimer's disease [24]. APP cleavage by $\alpha$-secretase (via the non-amyloidogenic pathway) generates two fragments, APPs $\alpha$ and C83. C83 is subsequently cleaved by $\gamma$-secretase, generating the pathologically irrelevant p3 peptide [25]. The presenilins (PS1 and PS2) are the catalytic core of the $\gamma$-secretase, so presenilin mutations - seen in Alzheimer's disease-could alter the activity of $\gamma$-secretase and $A \beta$ production [26]. Moreover, presenilin mutations could result in increasing the ratio of $A \beta 42 / A \beta 40$ [9].

Over the last five to six years, alternatives to the ACH hypothesis have emerged, namely a theory suggested by Morris and coworkers (2014) providing evidence that the process of (neuro)inflammation may be a "major player" in the pathogenesis of $\mathrm{AD}$, independent of $\mathrm{A} \beta$ formation [27] . In a similar vein, Clark et al. (2018) suggested a growth area for research into the treatment of neurodegenerative disease (e.g., post-stroke syndrome, traumatic brain injury (TBI), AD), could be to reduce chronically elevated levels of Tumor Necrosis Factor (TNF), and other cytokines-elevated levels of which, in turn, generate A $\beta$ [28] . While Morris et al. $(2014,2018)$ acknowledge that $\mathrm{A} \beta$ status may indeed predict the risk of dementia, they go on to suggest that a greater holistic approach to cognitive decline could further our understanding of this disease [27,29].

In addition to the aforementioned risk factors, obesity, cardiovascular disease, elevated cholesterol, hypertension and sedentary lifestyles also play a role in the development of AD [30-32].

Of those, a lack of physical activity is an important risk factor for the onset of dementia and Alzheimer's disease [32,33]. A summary of AD risk and protective factors is shown in Figure 1.

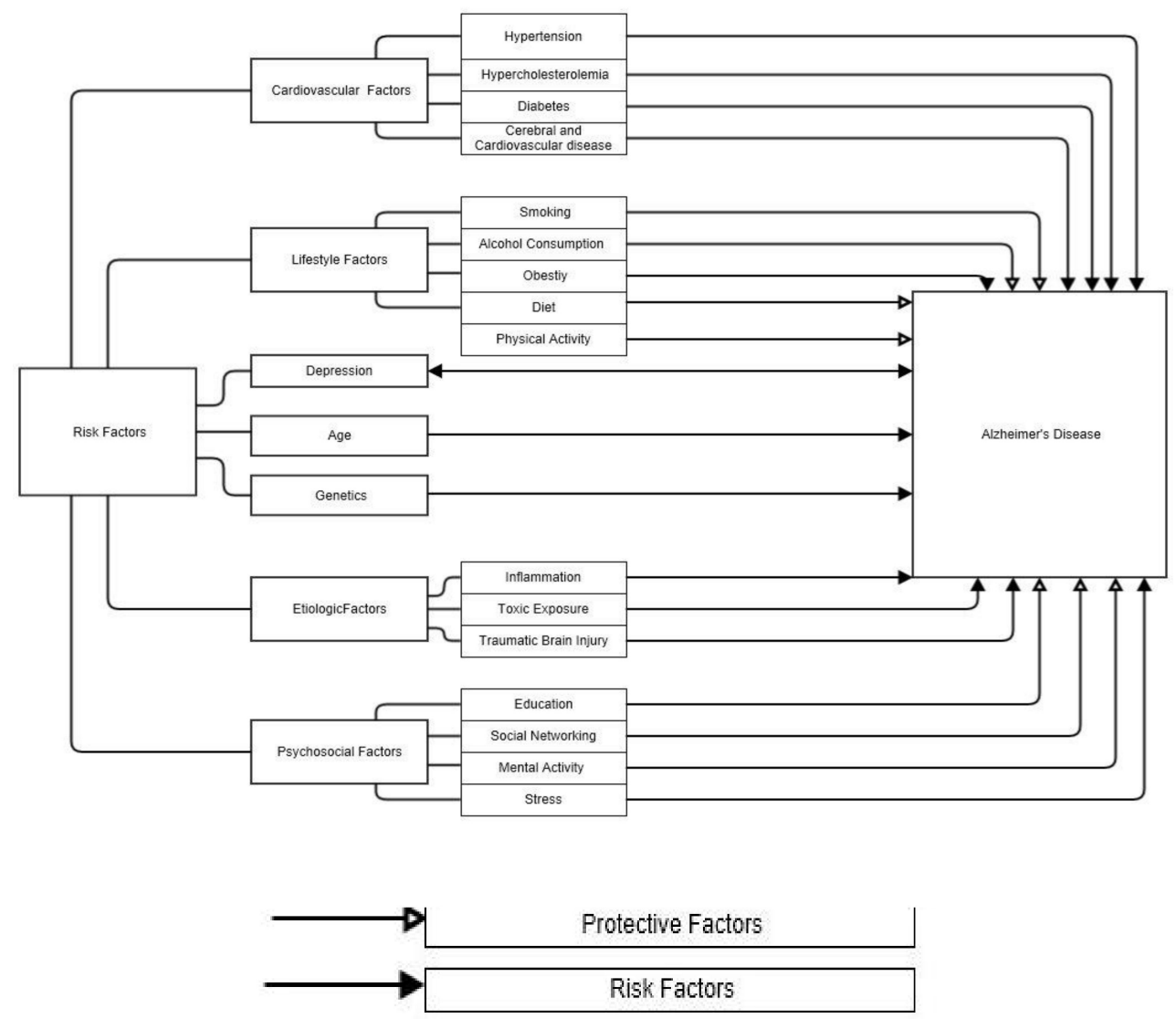

Figure 1. Protective and risk factors associated with Alzheimer's disease [34].

\section{Impaired Brain Creatine Kinase Activity and Cerebral Glucose Metabolism}

Lowered levels of brain creatine kinase activity and reduced cerebral PCr levels are associated with $\mathrm{AD}$ [35] and could be considered a risk factor in diagnosis. Creatine kinase (CK) activity is vital for 
the energy reaction of every cell in the human body as a spatial energy shuttle and energy sensor [35] and is thus paramount in bioenergetics of the brain [35].

The cerebral form of CK is known as cytosolic brain-type creatine kinase (BB-CK). AD patients manifest high levels of cytosolic brain-type creatine kinase (BB-CK) oxidative damage $[35,36]$. BB-CK activity in AD patients is reduced by to up to $86 \%$, coinciding with a $14 \%$ reduction in CK Protein expression [36] Reduced BB-CK activity in AD results in decreased ATP stores in neural cells and synapses $[35,36] \mathrm{BB}-\mathrm{CK}$ and the simultaneous expression of ubiquitous mitochondrial creatine kinase activity ( $\mathrm{uMtCK}$ ) is reduced in $\mathrm{AD}$ patients via high levels of oxidation, manifesting in BB-CK enzyme dysfunction and the progression of $\mathrm{AD}$ [35]. AD patients have mitochondrial DNA mutations manifesting in the dysfunctional cerebral bioenergetics of the brain [35] in essence, BB-CK activity is paramount in neuronal energetics, the facilitation of synaptic glutamate uptake and, ultimately, neurotransmitter uptake [35].

Another cerebral bioenergetic risk factor for $\mathrm{AD}$ is reduced cerebral glucose metabolism and mitochondrial DNA mutation [35,36].AD-associated mitochondrial DNA mutations result in perturbed energy metabolism in the brain and impaired central nervous system (CNS) function. Reduced acetyl-CoA production, cortical acetylcholine esterase activity, and oxidative phosphorylation are important risk factors in the onset of AD-associated senile dementia [35].

\section{The Effect of Physical Activity on Alzheimer's Disease}

Evidence from both human and animal studies suggests that physical activity, especially exercise that increases cardiorespiratory fitness, facilitates the neuroplasticity of certain brain structures related to cognitive function [37]. In a small, randomized controlled trial (RCT) study, six months of high-intensity aerobic exercise (75-85\% heart rate reserve) in patients with mild cognitive impairment (MCI), decreased the plasma concentration of $\mathrm{A} \beta-42$ [38]. Furthermore, $\mathrm{A} \beta$-dependent neuronal cell death in the hippocampus of NSE/PS2m mice (Tg) mice was markedly suppressed following treadmill exercise for 12 weeks from 24 months of age. These data strongly suggest that exercise provides a therapeutic potential for inhibiting both $\mathrm{A} \beta-42$ and pathways of neuronal death [39].

In rodent models, swim training five days/week, $1 \mathrm{~h} / \mathrm{day}$, for six weeks decreased tau phosphorylation and APP expression and improved spatial learning and memory in diabetic rats [40]. Similarly, three weeks of voluntary wheel running significantly decreased soluble A $\beta 40$ and soluble fibrillar A $\beta$ in aged Tg2576 mice (17-19 months), and the authors concluded that treadmill exercise may be beneficial in the prevention or treatment of $\mathrm{AD}$ [41], although experimental evidence is still needed from corresponding human studies. Consistently, A $\beta-42$ peptides decreased significantly in the NSE/APPsw Tg mice following exercise on a treadmill for 16 weeks. Furthermore, ten weeks of treadmill training in 1.5- to 4-month-old APP/PS1 transgenic (Tg) mice is known to enhance hippocampus-associated memory and amygdala-associated neuronal function and reduce the levels of soluble $\mathrm{A} \beta$ in the amygdala and hippocampus and serves as a means to delay the onset of AD [1].

It has also been demonstrated that treadmill exercise (TE) prevented PS2 mutation-induced memory impairment and reduced $\mathrm{A} \beta-42$ deposition through the inhibition of $\beta$-secretase (BACE- 1 ) and its product, C-99 in the cortex and/or hippocampus of aged PS2 mutant mice [42]. In addition, five months of treadmill exercise resulted in a robust reduction in $\beta$-amyloid $(\mathrm{A} \beta)$ deposition and tau phosphorylation in the hippocampus of APP/PS1 mice, which was also accompanied by a significant decrease in APP phosphorylation and PS1 expression. Thus, long-term treadmill exercise seems to mediate APP processing in favor of reduced $\mathrm{A} \beta$ deposition in animal models [43].

In human studies, it has been shown that there is a novel interaction between APOE status and exercise engagement [44,45]. Therefore, regular physical activity may reduce the risk or delay the onset of dementia and $\mathrm{AD}$, especially among APOE $\varepsilon 4$ allele carriers [46]. It has been suggested that exercise prevents the decline of neurovascular structure with age, but not in the absence of APOE. In other words, exercise has little or no effect on these changes in the absence of APOE [47]. A recent narrative review suggests exercise training and physical activity may have a significant role in the prevention of 
AD [48]. Taken together, these results suggest that exercise training represents a practical therapeutic strategy for humans suffering from AD [33], although differing modalities need to be explored with respect to effectiveness.

\section{Exercise, Memory and Learning}

There are many studies examining the effect of physical activity on memory and learning using rodent models. For example, five months of voluntary wheel running decreases extracellular amyloid- $\beta$ $(\mathrm{A} \beta)$ plaques in the frontal cortex and enhances the rate of learning and memory in TgCRND8 animals negotiating the Morris water maze, with significant reductions in escape latencies over the first three (of six) trial days [49]. Voluntary wheel running for ten weeks also reduced all the neuropathological hallmarks of AD, reduced neuronal loss, increased hippocampal neurogenesis and reduced spatial memory loss in a double-transgenic APPswe/PS1 $\triangle E 9$ mouse model of AD [50]. Lastly, four weeks of treadmill exercise prevented learning and memory impairment and the suppression of early long-term potentiation of CA1 area pyramidal cells in Alzheimer's disease-like pathology, again demonstrated in a rodent model [51].

In the aged animal, exercise is a very useful strategy for preventing memory failure. In one study, treadmill exercise improved short-term and spatial memories by enhancing neurogenesis and suppressing apoptosis in the hippocampal dentate gyrus of old-aged rats [52]. Consistently short bouts (4-6 min) of mild-intensity physical exercise during five consecutive weeks imporved spatial learning and memory in ageing rats [53]. Moreover, Van Praag et al. (2005) showed that voluntary exercise ameliorates some of the deleterious morphological and behavioral consequences of ageing in which a decline in memory in aged mice was reversed by running [54]. Therefore, aerobic exercise training, e.g., running, may improve memory and learning and be beneficial in reducing the risk or delaying the onset of dementia and AD in mice [39] and humans [39,46]. Another study carried out recently on rats suggested that voluntary resistance wheel running (to a maximum load of $30 \%$ of body mass) for four weeks led to improved spatial learning and memory and thus plays a beneficial role in hippocampus-related cognitive functions [55].

In contrast relatively few human intervention studies have examined resistance training with regard to learning and memory, dementia and AD. While resistance training has been performed in older groups, it has not been undertaken in individuals presenting with AD. For example, it has been shown that twelve months of resistance training in older women (65-75 years) may be a promising candidate for preventing cognitive decline and increasing cognitive performance [56,57]. Earlier results in elderly humans reported by Cassilhas et al. (2007) showed a significant and positive impact of resistance training at two different intensities (moderate and high) on cognitive function, as well as improving physical function. However, moderate-intensity exercise was more effective compared with high-intensity exercise for improving mood profile in the elderly [58]. A study by Perrig-Chiello et al. (1998) also resulted in improved cognitive function following an eight week resistance exercise program in 46 elderly volunteers (average age 73.2 years) [59].

A comparison between resistance and aerobic training has shown that both modes have a positive effect on cognitive function, as demonstrated in 36 volunteers aged 60-85 years performing 9 weeks of physical exercise. There was no difference between the two exercise groups (resistance versus endurance), suggesting that engaging in either form of exercise is beneficial, which may influence patient adherence based on personal preference [60]. Similar results have also been observed in a rodent model (90-day-old rats) undertaking eight weeks of aerobic training on a treadmill and resistance exercise on a vertical ladder, showing an improvement in learning and spatial memory in a similar manner, using either the Morris water maze test or a passive avoidance task [61]. A simplified diagram of how exercise may simultaneously improve memory, higher executive functioning, and act to reduce cognitive impairment, acting via multiple pathways to reduce inflammation [28] and enhance neural plasticity, is suggested by Figure 2. 


\section{Mechanisms whereby exercise can improve memory and cognition}

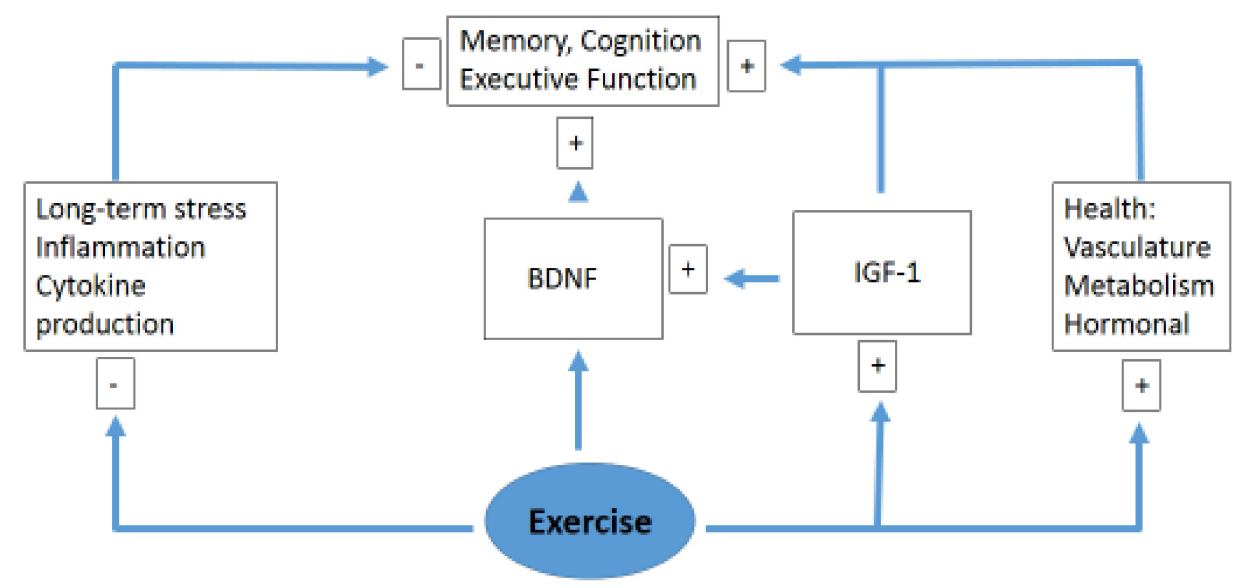

Figure 2. A simplified diagram of how exercise may simultaneously improve memory and cognition. Brain-derived neurotrophic factor (BDNF); insulin-like growth factor 1 (IGF1).

\section{Conclusions}

There is strong evidence to suggest exercise (in the form of endurance and strength training) appears to be a helpful non-pharmacological approach that delays dementia and Alzheimer's disease. The results of studies (both animal and human) in recent years show a positive effect of exercise on cognitive function and memory, as well as reducing risk factors for dementia and AD. However, there is limited research into the effects of resistance training on memory, learning and specific risk factors for Alzheimer's disease- the main finding of the existing (limited) research was that strength training had a positive effect on cognitive function and memory. Finally, those studies comparing the two modalities (endurance vs. resistance) found no difference; however, there is a paucity of studies to this effect and future research efforts should further consider these two modalities in the field of memory and learning, especially in AD. Ultimately, it is not known which type of exercise (strength or endurance) is more effective in this area and which could take precedence.

Funding: This research received no external funding.

Conflicts of Interest: The authors have no conflict of interest to declare. CPE is a paid research consultant for Naturally Slim, Inc. (Dallas, TX, USA).

\section{References}

1. $\quad$ Lin, T.-W.; Shih, Y.-H.; Chen, S.-J.; Lien, C.-H.; Chang, C.-Y.; Huang, T.-Y.; Chen, S.-H.; Jen, C.J.; Kuo, Y.-M. Running exercise delays neurodegeneration in amygdala and hippocampus of Alzheimer's disease (APP/PS1) transgenic mice. Neurobiol. Learn. Mem. 2015, 118, 189-197. [CrossRef] [PubMed]

2. Available online: https://www.who.int/news-room/fact-sheets/detail/dementia (accessed on 19 September 2019).

3. Chiba, T. Emerging therapeutic strategies in Alzheimer's disease. In Neurodegenerative Diseases; Kishore, U., Ed.; IntechOpon: London, UK, 2013; ISBN 978-953-51-1088-0.

4. Perrin, R.J.; Fagan, A.M.; Holtzman, D.M. Multimodal techniques for diagnosis and prognosis of Alzheimer's disease. Nature 2009, 461, 916-922. [CrossRef] [PubMed]

5. Bird, C.M.; Burgess, N. The hippocampus and memory: Insights from spatial processing. Nat. Rev. Neurosci. 2008, 9, 182-194. [CrossRef] [PubMed]

6. Ahlskog, J.E.; Geda, Y.E.; Graff-Radford, N.R.; Petersen, R.C. Physical exercise as a preventive or disease-modifying treatment of dementia and brain aging. In Mayo Clinic Proceedings; Elsevier: Amsterdam, The Netherlands, 2011. 
7. Alzheimer's Association. 2013 Alzheimer's disease facts and figures. Alzheimer's Dement. 2013, 9, $208-245$. [CrossRef]

8. Chen, W.-W.; Zhang, X.; Huang, W.-J. Role of physical exercise in Alzheimer's disease. Biomed. Rep. 2016, 4, 403-407. [CrossRef]

9. Welander, H. Alzheimer Disease: Studies on Abeta and Gamma-Secretase in Human Brain; Institutionen för Neurobiologi, Vårdvetenskap och Samhälle/Department of Neurobiology, Care Sciences and Society: Stockholm, Sweden, 2010.

10. Bradbury, K.E.; Guo, W.; Cairns, B.J.; Armstrong, M.E.; Key, T.J. Association between physical activity and body fat percentage, with adjustment for BMI: A large cross-sectional analysis of UK Biobank. BMJ Open 2017, 7, e011843. [CrossRef] [PubMed]

11. Daviglus, M.L.; Bell, C.C.; Berrettini, W.; Bowen, P.E.; Connolly, E.S., Jr.; Cox, N.J.; Dunbar-Jacob, J.M.; Granieri, E.C.; Hunt, G.; McGarry, K.; et al. National Institutes of Health State-of-the-Science Conference statement: Preventing Alzheimer disease and cognitive decline. Ann. Intern. Med. 2010, 153, 176-181. [CrossRef]

12. Xu, W.; Yu, J.T.; Tan, M.S.; Tan, L. Cognitive reserve and Alzheimer's disease. Mol. Neurobiol. 2015, 51, 187-208. [CrossRef]

13. Bertram, L.; Lill, C.M.; Tanzi, R.E. The genetics of Alzheimer disease: Back to the future. Neuron 2010, 68, 270-281. [CrossRef]

14. Schellenberg, G.D.; Montine, T.J. The genetics and neuropathology of Alzheimer's disease. Acta Neuropathol. 2012, 124, 305-323. [CrossRef]

15. Huang, Y.; Mucke, L. Alzheimer mechanisms and therapeutic strategies. Cell 2012, 148, 1204-1222. [CrossRef]

16. Poirier, J. Apolipoprotein E, cholesterol transport and synthesis in sporadic Alzheimer's disease. Neurobiol. Aging 2005, 26, 355-361. [CrossRef] [PubMed]

17. Hardy, J.A.; Higgins, G.A. Alzheimer's disease: The amyloid cascade hypothesis. Science 1992, 256, $184-186$. [CrossRef] [PubMed]

18. Armstrong, R.A. The pathogenesis of Alzheimer's disease: A reevaluation of the "amyloid cascade hypothesis". Int. J. Alzheimer's Dis. 2011, 2011. [CrossRef] [PubMed]

19. Karran, E.; Mercken, M.; DeStrooper, B. The amyloid cascade hypothesis for Alzheimer's disease: An appraisal for the development of therapeutics. Nat. Rev. Drug Discov. 2011, 10, 698-712. [CrossRef] [PubMed]

20. Juniper, K.C. American Colleage; The University of Oklahama Health Sciences Center Graduate College: Oklahoma City, OK, USA, 2002.

21. Rezaei-Ghaleh, N.; Giller, K.; Becker, S.; Zweckstetter, M. Effect of zinc binding on $\beta$-amyloid structure and dynamics: Implications for A $\beta$ aggregation. Biophys. J. 2011, 101, 1202-1211. [CrossRef]

22. Cole, S.L.; Vassar, R. The Alzheimer's disease $\beta$-secretase enzyme, BACE1. Mol. Neurodegener. $2007,2,22$. [CrossRef]

23. Sadigh-Eteghad, S.; Sabermarouf, B.; Majdi, A.; Talebi, M.; Farhoudi, M.; Mahmoudi, J. Amyloid-Beta: A crucial factor in Alzheimer's disease. Med. Princ. Pract. 2015, 24, 1-10. [CrossRef]

24. Joshi, G.; Wang, Y. Golgi defects enhance APP amyloidogenic processing in Alzheimer's disease. BioEssays 2015, 37, 240-247. [CrossRef]

25. Miras-Portugal, M.T.; Diaz-Hernandez, J.I.; Gomez-Villafuertes, R.; Diaz-Hernandez, M.; Artalejo, A.R.; Gualix, J. Role of P2X7 and P2Y 2 receptors on $\alpha$-secretase-dependent APP processing: Control of amyloid plaques formation "in vivo" by P2X7 receptor. Comput. Struct. Biotechnol. J. 2015, 13, 176-181. [CrossRef]

26. Marinangeli, C.; Tasiaux, B.; Opsomer, R.; Hage, S.; Sodero, A.O.; Dewachter, I.; Octave, J.N.; Smith, S.O.; Constantinescu, S.N.; Kienlen-Campard, P. Presenilin Transmembrane Domain 8 Conserved AXXXAXXXG Motifs Are Required for the Activity of the $\gamma$-Secretase Complex. J. Biol. Chem. 2015, 290, 7169-7184. [CrossRef] [PubMed]

27. Morris, G.P.; Clark, I.A.; Vissel, B. Inconsistencies and controversies surrounding the amyloid hypothesis of Alzheimer's disease. Acta Neuropathol. Commun. 2014, 2, 135. [CrossRef] [PubMed]

28. Clark, I.A.; Vissel, B. Therapeutic implications of how TNF links apolipoprotein E, phosphorylated tau, $\alpha$-synuclein, amyloid- $\beta$ and insulin resistance in neurodegenerative diseases. Br. J. Pharmacol. 2018, 175, 3859-3875. [CrossRef] [PubMed]

29. Morris, G.P.; Clark, I.A.; Vissel, B. Questions concerning the role of amyloid- $\beta$ in the definition, aetiology and diagnosis of Alzheimer's disease. Acta Neuropathol. 2018, 136, 663-689. [CrossRef] 
30. Wen, G. Alzheimer's disease and risk factors. J. Food Drug Anal. 1998, 6, 465-476.

31. Toda, N.; Ayajiki, K.; Okamura, T. Obesity-induced cerebral hypoperfusion derived from endothelial dysfunction: One of the risk factors for Alzheimer's disease. Curr. Alzheimer Res. 2014, 11, 733-744. [CrossRef]

32. Radak, Z.; Hart, N.; Sarga, L.; Koltai, E.; Atalay, M.; Ohno, H.; Boldogh, I. Exercise plays a preventive role against Alzheimer's disease. J. Alzheimer's Dis. 2010, 20, 777-783. [CrossRef]

33. Um, H.S.; Kang, E.B.; Leem, Y.H.; Cho, I.H.; Yang, C.H.; Chae, K.R.; Hwang, D.Y.; Cho, J.Y. Exercise training acts as a therapeutic strategy for reduction of the pathogenic phenotypes for Alzheimer's disease in an NSE/APPsw-transgenic model. Int. J. Mol. Med. 2008, 22, 529-534.

34. Ruth, S. Association between Physical Activity and Alzheimer's Disease. Master's Thesis, Institute of Public Health and Clinical Nutrition, University of Eastern Finland, Kuopio, Finland, October 2014.

35. Burklen, T.; Schlattner, U.; Homayouni, R.; Gough, K.; Rak, M.; Szeghalmi, A.; Wallimann, T. The creatine kinase/creatine connection to Alzheimer's diseease: CK-inactivation, APP-CK complexes and focal creatine deposits. J. Biomed. Biotechnol. 2006, 3, 35936.

36. Smith, R.N.; Agharkar, A.S.; Gonzalez, E.B. A review of creatine monohydrate supplementation in age-related diseases: More than a supplement for athletes. F1000 Res. 2014, 3, 222. [CrossRef]

37. Hötting, K.; Röder, B. Beneficial effects of physical exercise on neuroplasticity and cognition. Neurosci. Biobehav. Rev. 2013, 37, 2243-2257. [CrossRef]

38. Baker, L.D.; Frank, L.L.; Foster-Schubert, K.; Green, P.S.; Wilkinson, C.W.; McTiernan, A.; Plymate, S.R.; Fishel, M.A.; Watson, G.S.; Cholerton, B.A. Effects of aerobic exercise on mild cognitive impairment: A controlled trial. Arch. Neurol. 2010, 67, 71-79. [CrossRef]

39. Um, H.-S.; Kang, E.-B.; Koo, J.-H.; Kim, H.-T.; Kim, E.-J.; Yang, C.-H.; An, G.-Y.; Cho, I.-H.; Cho, J.-Y. Treadmill exercise represses neuronal cell death in an aged transgenic mouse model of Alzheimer's Disease. Neurosci. Res. 2011, 69, 161-173. [CrossRef]

40. Diegues, J.C.; Pauli, J.R.; Luciano, E.; Almeida Leme, J.A.C.; de Moura, L.P.; Dalia, R.A.; de Araújo, M.B.; Sibuya, C.Y.; de Mello, M.A.R.; Gomes, R.J. Spatial memory in sedentary and trained diabetic rats: Molecular mechanisms. Hippocampus 2014, 24, 703-711. [CrossRef] [PubMed]

41. Nichol, K.E.; Poon, W.W.; Parachikova, A.I.; Cribbs, D.H.; Glabe, C.G.; Cotman, C.W. Exercise alters the immune profile in $\mathrm{Tg} 2576$ Alzheimer mice toward a response coincident with improved cognitive performance and decreased amyloid. J. Neuroinflamm. 2008, 5, 2094-2095. [CrossRef]

42. Kang, E.-B.; Kwon, I.-S.; Koo, J.-H.; Kim, E.-J.; Kim, C.-H.; Lee, J.; Yang, C.-H.; Lee, Y.-I.; Cho, I.-H.; Cho, J.-Y. Treadmill exercise represses neuronal cell death and inflammation during A $\beta$-induced ER stress by regulating unfolded protein response in aged presenilin 2 mutant mice. Apoptosis 2013, 18, 1332-1347. [CrossRef]

43. Liu, H.L.; Zhao, G.; Zhang, H. Long-term treadmill exercise inhibits the progression of Alzheimer's disease-like neuropathology in the hippocampus of APP/PS1 transgenic mice. Behav. Brain Res. 2013, 256, 261-272. [CrossRef] [PubMed]

44. Head, D.; Bugg, J.M.; Goate, A.M.; Fagan, A.M.; Mintun, M.A.; Benzinger, T.; Holtzman, D.M.; Morris, J.C. Exercise engagement as a moderator of the effects of APOE genotype on amyloid deposition. Arch. Neurol. 2012, 69, 636-643. [PubMed]

45. Smith, J.C.; Lancaster, M.A.; Nielson, K.A.; Woodard, J.L.; Seidenberg, M.; Durgerian, S.; Sakaie, K.; Rao, S.M. Interactive effects of physical activity and APOE- $\varepsilon 4$ on white matter tract diffusivity in healthy elders. NeuroImage 2015, 131, 102-112. [CrossRef]

46. Rovio, S.; Kåreholt, I.; Helkala, E.-L.; Viitanen, M.; Winblad, B.; Tuomilehto, J.; Soininen, H.; Nissinen, A.; Kivipelto, M. Leisure-time physical activity at midlife and the risk of dementia and Alzheimer's disease. Lancet Neurol. 2005, 4, 705-711. [CrossRef]

47. Piotr, G.; Stefan, B.; Joanna, G.; Adam, Z.; Adam, M.; Roman, C.; Agnieszka, D.; Wojciech, C.; Robert, P.; Cain, C.T.C.; et al. Physical activity and Alzheimer's disease. Aging Dis. 2019, 10, 1282-1292.

48. Soto, I.; Graham, L.C.; Richter, H.J.; Simeone, S.N.; Radell, J.E.; Grabowska, W.; Funkhouser, W.K.; Howell, M.C.; Howell, G.R. APOE stabilization by exercise prevents aging neurovascular dysfunction and complement induction. PLoS Biol. 2015, 13, e1002279. [CrossRef] [PubMed]

49. Adlard, P.A.; Perreau, V.M.; Pop, V.; Cotman, C.W. Voluntary exercise decreases amyloid load in a transgenic model of Alzheimer's disease. J. Neurosci. 2005, 25, 4217-4221. [CrossRef] [PubMed] 
50. Tapia-Rojas, C.; Aranguiz, F.; Varela-Nallar, L.; Inestrosa, N.C. Voluntary running attenuates memory loss, decreases neuropathological changes and induces neurogenesis in a mouse model of Alzheimer's disease. Brain Pathol. 2016, 26, 62-74. [CrossRef] [PubMed]

51. Kim, S.-E.; Ko, I.-G.; Kim, B.-K.; Shin, M.-S.; Cho, S.; Kim, C.-J.; Kim, S.H.; Baek, S.-S.; Lee, E.-K.; Jee, Y.-S. Treadmill exercise prevents aging-induced failure of memory through an increase in neurogenesis and suppression of apoptosis in rat hippocampus. Exp. Gerontol. 2010, 45, 357-365. [CrossRef]

52. Dao, A.T.; Zagaar, M.A.; Levine, A.T.; Salim, S.; Eriksen, J.; Alkadhi, K.A. Treadmill exercise prevents learning and memory impairment in Alzheimer's disease-like pathology. Curr. Alzheimer Res. 2013, 10, 507-515. [CrossRef]

53. Aguiar, A.S.; Castro, A.A.; Moreira, E.L.; Glaser, V.; Santos, A.R.S.; Tasca, C.I.; Latini, A.; Prediger, R.D.S. Short bouts of mild-intensity physical exercise improve spatial learning and memory in aging rats: Involvement of hippocampal plasticity via AKT, CREB and BDNF signaling. Mech. Ageing Dev. 2011, 132, 560-567. [CrossRef] [PubMed]

54. Lee, M.C.; Okamoto, M.; Liu, Y.F.; Inoue, K.; Matsui, T.; Nogami, H.; Soya, H. Voluntary resistance running with short distance enhances spatial memory related to hippocampal BDNF signaling. J. Appl. Physiol. 2012, 113, 1260-1266. [CrossRef]

55. Van Praag, H.; Shubert, T.; Zhao, C.; Gage, F.H. Exercise enhances learning and hippocampal neurogenesis in aged mice. J. Neurosci. 2005, 25, 8680-8685. [CrossRef]

56. Liu-Ambrose, T.; Nagamatsu, L.S.; Graf, P.; Beattie, B.L.; Ashe, M.C.; Handy, T.C. Resistance training and executive functions: A 12-month randomized controlled trial. Arch. Intern. Med. 2010, 170, 170-178. [CrossRef]

57. Cassilhas, R.C.; Viana, V.A.; Grassmann, V.; Santos, R.T.; Santos, R.F.; Tufik, S.; Mello, M.T. The impact of resistance exercise on the cognitive function of the elderly. Med. Sci. Sport. Exerc. 2007, 39, 1401-1407. [CrossRef] [PubMed]

58. Peig-Chiello, P.; Perrig, W.J.; Ehrsam, R.; Staehelin, H.B.; Krings, F. The effects of resistance training on well-being and memory in elderly volunteers. Age Ageing 1998, 27, 469-475. [CrossRef] [PubMed]

59. Liu-Ambrose, T.; Nagamatsu, L.S.; Voss, M.W.; Khan, K.M.; Handy, T.C. Resistance training and functional plasticity of the aging brain: A 12-month randomized controlled trial. Neurobiol. Aging 2012, 33, 1690-1698. [CrossRef] [PubMed]

60. Özkaya, G.Y.; Aydin, H.; Toraman, F.N.; Kizilay, F.; Özdemir, Ö.; Cetinkaya, V. Effect of strength and endurance training on cognition in older people. J. Sports Sci. Med. 2005, 4, 300-313. [PubMed]

61. Cassilhas, R.; Lee, K.; Fernandes, J.; Oliveira, M.; Tufik, S.; Meeusen, R.; De Mello, M.T. Spatial memory is improved by aerobic and resistance exercise through divergent molecular mechanisms. Neuroscience 2012, 202, 309-317. [CrossRef]

(C) 2020 by the authors. Licensee MDPI, Basel, Switzerland. This article is an open access article distributed under the terms and conditions of the Creative Commons Attribution (CC BY) license (http://creativecommons.org/licenses/by/4.0/). 